\title{
FROM LUCY TO LANGUAGE: OUR PLACE IN NATURE
}

\author{
Donald C. Johanson
}

Founding Director, Institute of Human Origins, Arizona State University

My long-time experience in Africa has not only rewarded me with exceptional discoveries like LUCY, but also given me time to reflect on what I have discovered about our place in nature, and especially what the past tells us about ourselves.

When I was preparing today's comments I focused on one question: What has LUCY taught us since she first made her debut some 32 years ago?

As a young scholar my primary goal was to find fossils, the alpha evidence for human evolution. I was more fortunate that most, but I have grown to realize that while the bones are the primary quarry, it is the message they bring us from some long forgotten time that is most important of all.

Today I am increasingly interested in what LUCY tells us about where we fit into the rhythms of the earth. Is there something that connects us to nature, that transcends time and distance?

Just think, no other species has such a fascination with its origins as we do. No other species has the means to explore and discover fossilized clues to its beginnings. No other species has so much to learn from its past. But, sadly, no other species has so much to lose by ignoring its origins. I trace the roots of this philosophy back to my youth when I read Thomas Henry Huxley's book Man's Place in Nature (1863). I was intrigued by his proposition that humans are just another species, a result of the same process of evolution that brought about all other forms of life. I wanted to find the fossil clues, the Rosetta Stones for helping us decipher the secrets of human origins.

As a paleoanthropologist I knew that the story began in Africa. Darwin was right about that, our closest living relatives, chimps and gorillas live there today, he surmised we must have had a common ancestor.

I know some of you have been on Safari in Africa talk of being bitten by the Africa bug. Africa gets into our blood we say, but as the birthplace of the human family, Africa is already in our blood, in our bones and even in our genes.

Our DNA is $99 \%$ identical to that of the African chimpanzee. Imagine if we received a message from some far corner of the universe that astronauts found a hairy, quadrupedal creature so closely related to ourselves. We would be spending millions trying to understand what we could learn from this creature about ourselves. Today the chimp's habitat is quickly disappearing and who knows how many of the mountain gorillas still survive in the Rwanda.

Most of my research has focused on Africa's Great Rift Valley, a stunningly beautiful place. A jagged dueling scar on the planet's face that's the result of the slow grinding and shifting of the earth's crust, a tectonic tug of war.

The Great Rift Valley is a place of pilgrimage for paleoanthropologists; Hadar, Ethiopia is one of its shrines. This is where I found Lucy on November 24th, 1974. She's become an ancestral ambassador of sorts. Introducing me to more people than anyone alive. I always reminded of how much better known she is than her discoverer.

LUCY has been an incredibly successful ambassador. Bringing together people of very diverse backgrounds. We work with Muslims. The Koran doesn't have much of a place for evolution, but the nomadic, Afar understand that the world knows Lucy and they are proud that the first human was an Afar.

Lucy is important for many reasons and continues to be the subject of study by scholars world-wide. She has become an icon for paleoanthropology. The touchstone and benchmark by which all other fossil discoveries are judged. Older than, younger than, more complete than, etc. It is endlessly fascinating to me that after so many years and the discovery of much older and even more complete finds, Lucy is still the focal point of discussion among anthropologists and the laypublic alike.

At a dinner party when someone brings up the idea of human ancestors and people admit they know nothing about human evolution, someone mentions Lucy and people perk up, as if they have brought up the name of a relative and in a funny way she really is a relative, for all of us.

Lucy is the link to our common origin with the African

Correspondence to:

Professor Donald C. Johanson, Ph.D., Physical Anthropology.

Founding Director, Institute of Human Origins

School of Human Evolution \& Social Change, Accademic Unit of the College of Liberal Arts and Sciences

SHESC 233 I P.O. Box 872402, Tempe, AZ 85287-2402, Phone: 480-965-62 13 | Fax: 480-965-7671

e-mail: johanson.iho@asu.edu 
apes. But Lucy has an even more important message for us; she is a link to the natural world. The more links we find, the closer we see ourselves to the natural world. We are part of the continuum of life. The more we learn about our closeness to Nature the more we see ourselves as part of Nature and not distinct from it. We cannot turn our backs on the very natural world that created us and all other life on this planet.

Discoveries over the last three decades have shown us that the tree of life is just as Darwin predicted; a tree with many branches, all of which went extinct, except the one that led to us. In this regard I find it fascinating that still so many people think of human evolution as a straight line from ape to angel; and we know who the angel is supposed to be.

Think about for a minute, I am sure you have seen those little depictions of creatures evolving from all fours to upright humans. And who is the pinnacle of human evolution, the White European Male! Why?

Because white European males drawn those pictures. I love to say that Lucy is the woman who shook up man's family tree!

Tonight I am not going to debate who's version of the human family tree is the right one, for there are as many interpretations as there are anthropologists. But anthropologists agree on one primary and inescapable conclusion, Africa is the cradle of humankind.

All the major steps in human evolution: bipedal walking, the first stone tools, brain expansion, the first appearance of Homo erectus, the first Homo sapiens, all premiered in Africa.

So, no matter which branch of the human family tree you grasp, the roots, inevitably lead back to Africa, the continent of our origins. We, as a species are united by that past and by accepting this conclusion we realize, in spite of superficial difference, such as skin color, we are one, all with a common origin.

Let me return to extinction. Extinction is the rule in the evolution of life, not the exception. $99 \%$ of all species, since the beginning of life on this planet, have gone extinct!

Here is an important message for all of us. Just because Lucy's ancestors stood up four million years ago didn't mean that modern humans were destined to arise, we were not inevitable.

We and our ancestors were susceptible to the same vagaries of climate and environmental change, we could easily have gone extinct, also. As my later colleague Stephan Jay Gould said, if the tape is rewound and played again, there is no guarantee that we would be here tonight talking about OUR origins.

Modern humans are unique, don't' get me wrong, we are separated by a huge gulf from our closest living relatives, the African apes. Sure they use very rudimentary tools and in a laboratory can learn an amazing number of words, but no other species composes operas, writes poetry, paints great art, contemplates the future, or ponders the past, only us.

My work has led me to appreciate our place in the natural world. We belong here as much as any other species, but we have inherited an awesome responsibility as the most intelligent creature on the earth. Whether we like it or not, we are the guardians of the planet! A frightening, but unavoidable conclusion.

Humans are consumed by an egocentric view that we are the pinnacle of evolution. But, looking at ourselves in the broader perspective of evolutionary time provides us with a very different and humbling point of view.

Just imagine for one moment, LUCY's species, Australopithecus afarensis, walked the earth for at least a million years, ten times longer that Homo sapiens has existed. Here we sit in the 2 lst Century and futurists are asking if we as a species will survive the first few decades of the third Millennium. BUT, when we look though the lens of time, to equal the time that LUCY's species spent on earth, modern humans will have to

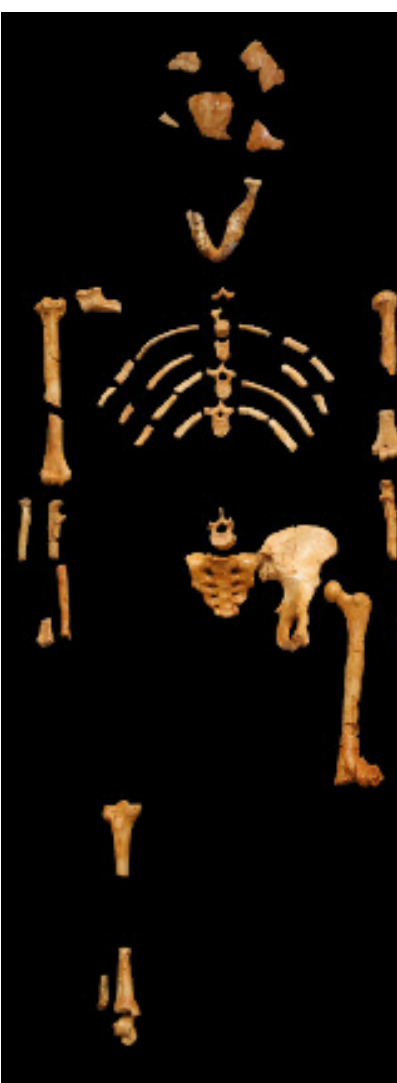

Lucy » skeleton (AL 288-1) Australopithecus afarensis, survive not just the next century, but live for another 9,000 centuries beyond that! What a humbling notion! I am convinced that understanding the ancient, evolutionary legacy that still resides in our modern psyches is vitally important, because such knowledge undoubtedly will play a role in our survival, indeed the survival of all life on this planet.

We may live in modern cities, but in may respects we still operate with a stone-age mind. Our rapidly accelerating technological evolution has far outpaced our genetic evolution that is virtually identical to that of our hunter - gathering ancestors - there is a vital imbalance here.

Can a psyche that evolved in the Paleolithic successfully cope with the modern world? Will we overcome the primitive urges and replace them with enlightened compassion for our fellow man?

While we may be the most intelligent, dangerous and cooperative animals to walk the earth, we are not the final resting point of life's three billion-year adventure. Our species is still an evolutionary work in progress. The future is upon us now; we have the power to influence the outcome of all life on this planet. It is my hope that is egocentric species will become the introspective species and make choices that will not only benefit us, but all of our fellow travelers in the great mystery of life.

I am hopeful that an increased awareness of the deep biological roots we share with one another, in fact, with the entirety of nature, will point us in the direction of our best dreams rather than our worst nightmares... 